UDK 82(100)-31.091"18":791.43"1987/1999"

\title{
DAUGHTERS, DEATH AND DESIRE IN FATAL ATTRACTION, THE PIANO AND THE TALENTED MR RIPLEY
}

\author{
Naomi Segal
}

\begin{abstract}
The oedipal principle characteristic of the nineteenth-century novel of adultery survives into twentieth-century narrative fiction too, as exemplified in two films of the late century, Fatal Attraction (1987) and The Piano (1993). In both, a marriage is disrupted by the desire of an outsider. This article begins with that comparison, and then it turns to a third example of triangulation, The Talented Mr Ripley (1999).
\end{abstract}

Key words: Oedipal principle, triangulation, adultery

In the 1990s, I published two books on the fiction of adultery: The Adulteress's Child and Scarlet Letters; in 1986 and 1988 I had published two others on a sub-genre of romantic fiction in a confessional mode, mainly in French, which I called the récit. In each of these two major genres of nineteenth-century prose writing, the focus is on male desire of an oedipal kind, and it is not surprising that the desire represented is triangular, infantile and tragic. This oedipal principle characteristic of the nineteenth-century novel of adultery, such as those of Flaubert, Stendhal, Fontane, Tolstoy and Hawthorne, survives into twentieth-century narrative fiction too, as exemplified in two films of the late century, Fatal Attraction (dir. Adrian Lyne, 1987) and The Piano (dir. Jane Campion, 1993). In both, a marriage is disrupted by the desire of an outsider. This article begins with that comparison, and then it turns to a third example of triangulation, The Talented Mr Ripley (dir. Anthony Minghella, 1999), in which disruptive desire works in a different way, implying entry not so much inside the couple as inside the body of the other.

Marriages are, of course, rarely simply configurations of two. I argued in The Adulteress's Child that the structure of adultery in the male-authored nineteenth-century novel depends not so much on the normative triangle of husband, wife and lover as on another, coexistent and I believe primary and more powerful one: that of lover, beloved and child. In almost all the texts I looked at, the lover is an unmarried young man, the beloved is older, married and a mother. The texts fall into two groups which I called those of the "patrilinear mother' and those of the 'matrilinear mother'. For the purposes of the exploration of the daughter's role in my first two films, I shall briefly summarise the logic of the latter. 
The mother of a daughter in the male-authored novel of adultery is presented as already implicitly outlawed by the birth of a child (whether legitimate or illegitimate), who does not offer her the iconic gratification of a Mary or a Jocasta but rather the vicious circle of 'only' being able/permitted to reproduce herself. The clearest example is Flaubert's Emma Bovary who, after giving birth, frustrated of the vicarious satisfaction of having a son, turns to the wall and faints. In Madame Bovary, Anna Karenina, The Scarlet Letter and Effi Briest, all texts focalised on the person of the desiring woman, the mother/daughter pair is represented as imprisoned - in a garden, village or cell and the mother is unable to escape this enclosure into jouissance. Instead, the daughter alone eventually leaves the closed space and is reinserted, often through a version of fostering by the abandoned husband, whether her father or not, into the genealogy of legitimacy.

Fatal Attraction and The Piano are both fictions in which the adulterous triangle is complemented by a matrilinear maternal triangle: in the former this consists conventionally of the wife, her daughter and the female rival, in the latter of the wife, her daughter and the piano which reproduces them both in different ways. In examining the place of the daughter in the two films, we shall see how differently this figure (and her comic adjunct, the dog $)^{1}$ may distend the principle of triangular desire in a late twentieth century genre. In particular, we shall trace the differences between representations of, in turn, masculine and feminine desire.

Fatal Attraction was a massively popular film: in it, the brief banal adultery of a 'nice guy' (Michael Douglas) married to a pretty, domestic wife (Anne Archer) leads to the extreme uncanny of the hell-hath-no-fury vengeance of female jealousy. Alex (Glenn Close), the spurned mistress, represents the ingress of the excessive feminine - whose quasi-phallic power is marked by her ambiguous name - into the domestic space. In the closing climax (which refers fairly explicitly to the early climax of Psycho, where another uncanny feminine figure irrupts into the steamy space of a bathroom), it is finally the wife who kills the madwoman, after the latter has risen from the bath in which the husband had apparently drowned her. This film led to a spate of others in which two phenomena stand out: a final murder that proceeds via an uncanny resurrection, and a figure conventionally positioned at the subordinate margin of the domestic space who breaks out and breaks in. The two elements hang together: like the cancerous swarms or monsters of most horror movies, this irruption of the 'mistress (servant/ policeman/ plumber/ nanny/ flatmate) from hell' blasts oedipal domesticity wide open, and is defeated only by a 'justified' violence on the part of the safe structure, which then closes again, doubly endorsed by its bloody happy ending. The movie ends on a happy clinch alongside a close-up of a photograph of husband, wife and daughter in a smiling embrace.

Small quantities of gender/sexual uncertainty - just enough to show us why nice men have flings - are already there in the home space. The husband Dan is feeble, the couple never seem to have time to make love because the dog must be walked or the child cuddled, the child herself (like the mistress) is both not quite feminine in looks and extremely feminine - 'cute', always clutching a pet or a toy - in function; Beth the

\footnotetext{
${ }^{1}$ The tangential-essential dogs in these two films, and in a number of other texts, will be the subject of a monograph currently in progress: Six Strays: Fictional dogs from 1845 to 1992.
} 
wife alone is rock solid in her gender definition, the perfect female partner whether in tears or shiny smiles. Alex, by contrast, smiles increasingly uncannily as her 'madness' grows. Michael Douglas is always fazed by her, his strong-jawed pose representing panic rather than strength. Parallels between the panting that follows 'excessive' sex and that after he has tried to strangle her suggest (as in all femme fatale fictions, in which male violence is attributed to the uncanny power of its victim) that his malevolence as well as his desire originates in her, even or especially when it is directed against her.

An ironic use of white in Alex's costumes and decor echoes the white in the costumes and decors of the family; darkness along with threatening long chords, or jagged camera-angles and rapid cuts conventionally suggest menace, montage is used to build up suspense in the scenes of the boiled rabbit and roller coaster/car accident. In all these familiar ways, the genre effects are predictable enough, as are the various uses of domestic objects in audial or visual close focus: the car, the bath-tap, the saucepan, or (repeatedly and sometimes ambiguously) the telephone. What is more interesting is the occasional variety of angles of entry into the family scene. Shots framed by window or doorway for instance, or sections of house as approached or entered by the camera, suggesting the viewpoint from the angle of the aggressor/interloper - as classically in the first Jaws (dir. Steven Spielberg, 1975) - create an ambiguity of predation. I will return to this in a moment.

The central adulterous triangle here is that of husband, wife, mistress (in that order) with the husband as dominant (though not exclusive) focaliser, both in a practical and an unconscious sense. The domestic triangle consists of husband, wife, daughter and their extensions in inanimate and animate objects: homes, domestic accessories, a male dog (unwilling abetter of adultery and slurper-up of the evidence) and a female rabbit (traumatically steamed - in a rehearsal for the wife?). Further, there is what I have called the maternal triangle of wife, daughter, mistress, with the latter borrowing the child and returning her after this 'robbery' has wounded the mother and enraged the father.

The child's role as simultaneously interloper and completion of the oedipal couple is shown in various predictable ways: they beam together at her antics, she answers the phone after he has left and communicates for him with Mommy, she is blinkingly sweet in the marital bed when he has just psyched up for sex. (As Mandy Merck notes, the only scene that does not seem to rouse and implicate her is the surely very noisy murder scene, in which she is obviously inessential: see Merck 1993: 210-11). Alex's relation to Beth's daughter seems oddly benign, as if we are to guess she really is pregnant and would possibly make a devoted mother. ${ }^{2}$

We are never entirely sure if Alex really is pregnant, but her repeated claim on Dan is not just on her individual behalf but on that of the mother/child couple she now forms: he has entered her and stayed, having left behind that 'part' of himself that she continues to contain. In precise reciprocation she lays claim on his bodily territory, extended into all those feminine units by which he is surrounded. Thus her successive attacks - on him (the ravenous sex), his car (destroyed and implanted with a tape), his office (by phone, censored by the well-schooled secretary) and flat (comically entered

\footnotetext{
${ }^{2}$ In the DVD of 2002, Sherry Lansing recalls that the development of the movie from a short by James Deardon began when she suggested 'what if she's pregnant?'
} 
as a potential buyer, setting up a brief alliance with Beth), the rabbit, the daughter and finally, the Gothic-cosy country house and its angel the wife - are so many ripostes for a derisory entry which never quite got out. I mentioned a moment ago the ambivalence of predation. Alex's own space is repeatedly shown as empty and pitiable; but, for all her grotesque excess, she is sometimes offered as the rightful viewpoint - not least on both occasions when he almost murders her - against a phallic pleasure that is always intrusive. ${ }^{3}$

The focalisation on the man is doubtless the source of the film's unpleasant power: masculine terrors arise directly out of the desire to 'have it all', to be the object of the ravenous woman as well as that of the bruised, devoted wife, to be (as Alex puts it) gutless, hopeless, sexless even, and still passionately desired. Finally, however, he can neither kill nor save, both these acts being the prerogative of the wronged wife and the only kind of revenge she is permitted - for whose sake exactly is not made clear. Yet, while the film is sometimes ambivalently focalised on Alex too, we are, I think, never (even at the end) invited to share in the viewpoint of the wife. If this is a mixed masculine fantasy, and the arousal and chastisement of all those 'bad modern women' who have too much greed and too much hunger to survive their little bit on someone else's side, where the audience is never put is in the space of the mother/daughter pair of healthy surviving females who just possibly feed off everybody else.

The Piano is, on the contrary, entirely a film of and about female desire. In this sense it is unconventional and anti-oedipal, and the mother/daughter unit functions to reshape the conventional couple by holding it open rather than sealing its closure. The daughter (Anna Paquin) is a much more central figure: she is, in turn, the mediator and the disruptor of desire, and she successively forms three couples - with her mother (Holly Hunter), with the husband (Sam Neill) and with the lover (Harvey Keitel) - until, after a number of crises, she ends up completing a secure domestic triangle in the city with Ada and Baines. With a couple of exceptions, I have encountered only women who were powerfully moved by the film and men who were not. Clearly this has something to do with the power of Ada, the focalised but silent protagonist, and the process whereby the projections of her body are gradually liberated (rather than intruded upon) by her lover.

The film is heavily stylised, with a visual and audial beauty that many viewers call 'haunting'. That it is also sometimes comical - often in sections that are quite threatening for women - is a curious extension. The lighting is relentlessly natural, with only occasional uses of the shades of red, and dominated by a blue shading that anticipates the resurrection by water of the woman when she abandons the piano - a teasing reference to the resurrection of Alex from the bath? - by making the landscape the same encompassing pre-natal medium from which passion has to emerge. Close-ups are rare, and then on faces which are always thin-lipped (except the daughter's) and dark-eyed (except the husband's). There are a large number of visual parallels: the costumes, hair and hats of mother and daughter; the use of hands to speak, play or caress; the analogy of fingers, keys, territorial markers, etc. Interestingly, none of these formal doublings,

\footnotetext{
${ }^{3}$ Indeed, in the original ending, Alex commits suicide in the manner of Madame Butterfly leaving Dan to take the blame; this ending was strongly preferred by Glenn Close who played Alex as abused rather than abusing (Fatal Attraction DVD); see Segal 2015.
} 
however 'haunting' or enigmatic, seem to make the film uncanny. A certain element of the sinister, of horror is lacking. Is this because, despite moments of cruelty and wildness, none of the characters is actually malevolent? In particular, I am struck by the ambivalence of the lover's predation: he bargains Ada into sex by offering to give her back the piano key by key but his inroads into her body and 'heart' are made with timidity, patience and respect, allowing her desire to emerge without the violence that characterises her silence.

In the opening shot we are peeped at through redly lit fingers wearing a wedding ring, and hear a few introductory lines in a childish voice. Then - again led in by the view of flailing hands caught - we see the first, maternal triangle, the complete circle of Ada's world: mother, daughter and piano, landed on a foreign beach. The adequation and exploitation of the child as a substitute for voice is shown when she pronounces Ada's aggressive message to the sailor and only escapes his fist by hiding in her mother's skirts. Their first night is spent inside the tent of the mother's crinoline, again a complete enclosure, in which the couple are united in a familiar retelling of a bedtime story without words. Both men (as well as the curious Maoris) will later try to get under this crinoline, with varying success.

The contrast between the two men is shown in Stewart's disappointed 'You're small' - he has, after all, presumably bought her - and Baines's 'She looks tired'. Twothirds only of the original triangle is taken to the marital home, the piano remaining behind on the beach. The entire question of the first half of the film will be: how is Ada to reenter into possession of her piano? The question of the latter half is: how is she to release herself and her passion from its dependence on the piano?

In this film, unlike Fatal Attraction, triangles are systems of mediation rather than the normalised adulteration of couples. At first, the child is, along with the piano, the instrument of the woman's physicality. Baines succeeds in 'winning' Ada where Stewart fails surely because he understands the significance of the piano not so much as a commodity extension of the woman and her body, but as a means to reach her. $\mathrm{He}$ begins by taking her to it, standing as audience to the enclosed triad of mother/child/ instrument on the beach; then uses it to bring her to him, listening silently as she reappropriates it by playing. At this point, the child as mediator becomes redundant to the newly formed triangle of woman, piano and man. It is of course essential that Baines cannot read, so that the instrument is the only mediatory means between them. Gradually, through the simultaneously comic, threatening and reassuring eroticism of Baines's clumsy 'bargain', the woman's body reenters the communicative circuit, replacing both piano and child. (This is the phase where the dog appears, imitating wistfully outdoors the sexual lapping of Baines within the hut.)

The daughter is also shut out of the system as the two lovers enter a dyadic phase of passion. This is not only involuntary: as she takes her place in the social circuit of the Scottish bourgeoisie in the extended community of the bush colony, and begins to call Stewart 'Papa', she detaches her loyalty from the mother whom hitherto she both protected and enjoyed. In a realistically justified pique, now the object rather than the mouthpiece of her mother's 'will', she makes the first of two transfers of loyalty, betraying the adultery to the husband at precisely the moment when Baines has decided to let go, wanting Ada's 'heart' rather than her body and giving back the piano now that he 
no longer has a use for it.

It is essential that, after the interlude of Ada's imprisonment, the dénouement proceeds without the piano: the daughter acts the part of vengeful angel (the Hebrew mal'ach, translated as 'angel', means messenger), carrying first the key and then the severed finger to the two men in turn. It is she whom Stewart finds in bed with Baines when he comes to kill him and leaves having 'given' him Ada instead.

The ending has annoyed many viewers, perhaps because it is probably unique in fictions of adultery in permitting the survival of passion into happiness, perhaps because of the abandonment of the piano, in which many people identify the film's source of libido. But Ada, whose narrating voice reappears as she rises up through the water, and continues - with what appears an almost unseemly perkiness - to the end of the frame, recognises a choice of the will to live in the detachment from that instrument of communication. At the point where the piano is discarded, the daughter, it seems, is also released from her mediatory functions. Uniquely in the matrilinear fictions of adultery (and I dare say that this is because it is a female-authored one), the mother, the lover and the daughter survive together into a normalised illegitimacy in the end.

Minghella's The Talented Mr Ripley offers a quite different version of triangular desire. It is not a fiction of adultery, and death, for its ruthless protagonist, is not an option but a necessity. How Tom Ripley (Matt Damon) will use and destroy others, chiefly his object of aspiration Dickie Greenleaf (Jude Law), in order to be someone he has not had the opportunity to be, is triangulated in a number of ways: through a series of splits in the self - stripes across Damon's face in the opening and closing sequences, repeated flashes of body fragments in Italy's ancient sculptures - and also through a repetition of perfect moments disrupted: there is always a knock at the door, a twist, or a meeting that has to be conducted in front of a third party. Indeed, the main adaptations Minghella has made to Patricia Highsmith's novel of 1955 are elements of mediation added in to what is intrinsically an individual, secret, anti-dyadic desire.

Desire for Tom Ripley is not the wish for an encounter, whether between bodies or minds, but for a reverse incorporation of the other, not engulfment but entry into the other's self, mode or space. This wish enacts neither of the 'normal' versions of person-to-person predation: penetration or caress. Instead it is the wish to be where, who and what the object is. This might seem to be the most extreme opposite of mediation, but it turns out, instead, to be a struggle to the death with the impossibility of avoiding mediation.

Like his girlfriend Marge (Gwyneth Paltrow), Dickie represents a class born to fine objects and limitless cash changed at American Express offices under the eyes of obliging functionaries. He is beguiled by Tom's artful borrowing of his own passions: jazz, Italy. But when he tires of him, as Marge has warned he will - 'The thing with Dickie: it's like the sun shines on you, and it's glorious; and then he forgets you and it's very very cold; when you have his attention, you feel like you're the only person in the world, that's why everybody loves him so much' (cited Ripley DVD: n. p.) - Tom murders him, moves to Rome, takes on that luxurious world - until upper-class Freddie (Philip Seymour Hoffman) finds him out, and he must be murdered too. Thereafter the talents are turned to the art of evasion: Tom and Dickie by turns, depending whom he is with, brilliantly covering the tracks of both, he finally faces Marge, who understands 
everything but is ignored; Dickie's father, who has decided his son is the culprit and is best buried; and Peter Smith-Kingsley (Jack Davenport), with whom he might have been happy but whom he is forced in the end to kill as well.

I want to argue that the rising series of murders characterise not simply Tom's choices of worlds in which to disappear but a particular kind of self-loss. Both Highsmith's novel and René Clément's 1960 film Plein Soleil are, in different ways, studies of a gifted and unlikeable go-getter, a petty criminal who supplements his many lucky breaks with a talent to amuse and an opportunistic ruthlessness (see Williams 2004). In both cases the idea of killing and impersonating Dickie - Philippe (Alain Delon) in Plein Soleil - precedes the moment of murder and the motive is predominantly practical. Minghella's Ripley is written in a tragic mode, more psychologised, and even though Highsmith's third-person narrative does not prevent us from entering him sympathetically, Minghella requires us to experience through his viewpoint the trajectory that takes him from the basement to the sunlight and back again, ending with the terror of having murdered his true love-object and remaining in darkness for ever.

If in Highsmith the motive of murdering Dickie is tied up with the enigma of Tom's sexual repression, and in Clément with a simple case of financial and heterosexual rivalry, in Minghella it is something else again, based in but not limited to a broader class fetishism: Tom wants what Dickie both is and has. Dickie is clothed in the ease and charm of those born to wealth: his skills (playing the saxophone, swimming, skiing) never seem to have to be rehearsed, whereas we watch Tom practising the identification of Chet Baker or Charlie Parker just as he practises Italian; and he has to pretend to like jazz - his own taste is for classical music - until the joy of singing with Dickie in a jazz club seduces him to share its pleasure. Once he has killed Dickie, he uses his money to enter that world, and the world is the body: we see him smooth and assured in his new suits, having cast off his glasses like the proverbial Hollywood heroine, using Dickie's voice and wearing his rings.

By the use of a number of additions or developments of characters (Silvana, Meredith Logue, Peter Smith-Kingsley), Minghella opens up the path of desire to mediation and complication. Another way that it is amplified is by the indirection of its aim. In The Talented Mr Ripley, there is only one object of desire, Dickie; and the others (Marge, Silvana, Meredith, Freddie) vie in creating ways of coming closer to him. They all fail: Tom alone goes far enough in taking on the object as his skin and disguise. And yet, I want to argue, even when doing this Tom cannot reach the goal he seeks: by entering Dickie's 'self' he would like to put on a kind of immediacy, a non-triangulated state that, actually, the very means and manner of his desire make impossible.

If Tom does not simply want Dickie himself what does he want that only 'being Dickie' can allow? We have already seen that he wants what Dickie has - what he takes on are Dickie's clothes, name and things. These objects have an air of fetishism not only because they are another mediation, representing the wealth that makes them possible, but also they can - must, by the interloper - be appropriated caressively. They are surfaces of desire - fine leather, velvet, cashmere. When briefly, on a train, Tom lays his cheek on the surface of Dickie, it is his lapel he reaches for, not his skin (as, later, just before strangling him, he lays his cheek on Peter's sweatered back). But this is not, I think, a way of reaching Dickie, it is something more like 'learning' his surface. Dickie's clothes are his skin, they contain his solar glow as their extension, exactly as 
Princess Diana's fabled outfits contained hers. The metaphor of sunshine, used both in the screenplay and in the director's commentary, is not a positive one: Dickie as played by Jude Law is 'so sunny, such a sun-god', but his skin is a reflective rather than radiant surface: his surface has a 'metallic, cruel' quality. By contrast, Minghella refers to Tom having to return to a dull texture, 'the corduroy jacket' (AM commentary) when he gives up the Dickie persona to hide from the police. ${ }^{4}$ What Tom wants is to slough off the corduroy and metamorphose into something whose surface radiates.

Like a foetus, Dickie scarcely knows desire, so quickly are his wants met by the world he glides through. Tom wants to stop desiring. In Dickie he might be able to take a break from it; Dickie does not need to long for anything, it is at once his. He magnetises the wishes of others, and this is what radiates from him, what he laughs off. Tellingly, when this momentarily fails, at the point of Silvana's suicide, he strikes out because he has no strategy for frustration. Tom, let us say, wants Dickie's ability not to waste time on desire, but to exist instead on the gleaming surface of things, himself being the surface of the things others look at. Unlike in Plein Soleil, this is not the triangulation of jealousy or envy; but a wish to be a still point that is the indifferent site of other people's passions.

'The main thing about impersonation, Tom thought, was to maintain the mood and temperament of the person one was impersonating, and to assume the facial expressions that went with them. The rest fell into place' (Highsmith 1999: 114). This must be what is meant by 'talent'. Tom barely needs to imagine what it is to be as unimaginative as Dickie, already he can play it. But he can only ' $b e$ ' Dickie when the latter is dead. And similarly he cannot play Peter because the latter is there, offering to supplement Tom as his accepting other. Tom Ripley does not want - or, he thinks, he must not want - any other. And yet what he discovers is that this is impossible. In The Talented $\mathrm{Mr}$ Ripley, the only way to desire is through death. The murder of the beloved other is the only means to 'having' them. What remains, after the death of the other, is the impossibility of either immediacy (Dickie) or intimacy (Peter): a fraught, riven, isolated self. I think this is what the ending is meant to convey: if Tom's inner space exists at all, it is as a place where 'self' can no longer be shifted out into a gestural, careless surface, but is established as an inescapably hidden, 'locked', secret, nasty, endlessly mediated and unreflecting thing.

What, then, do these three versions tell us about triangular desire? In the first, we have the most traditional mode of oedipal mediation: the family a gently expansive unit threatened by its own permeability, closing ranks in a retrenchment cemented by the outsider's blood. In the second, mediation is not a threat, it is a lifeline - but it too has to be disciplined by the closure that is dyadic love: Ada must lose her piano if she is not to lose her one chance at normality. In the third we have a story that by-passes dyadic love altogether: no one in this bleak world is safe with a desire that is cannibalistic by its very nature but which, finally, collapses both two and three into a self-triangulating one.

\footnotetext{
${ }^{4}$ Actually in Highsmith, it is Dickie who wears a corduroy jacket (Talented Mr Ripley, 114) - significantly on the day Tom murders him. Can this be connected to the fact that while Tom's gaucheness is typified by strikingly 50s-looking clothes (woollen trunks, hideous glasses), Dickie's beachwear and elegant suits seem much less dated?
} 


\section{WORKS CITED}

Campion, Jane (dir). 1992. The Piano DVD (1999). Ciby 2000.

Campion, Jane, The Piano screenplay. London: Bloomsbury, 1993.

Highsmith, Patricia. The Talented Mr Ripley. London: Vintage, 1999 [1955].

Lyne, Adrian (dir). 1987. Fatal Attraction DVD (2000). Paramount.

Merck, Mandy. Perversions: Deviant Readings. London: Virago, 1993.

Minghella, Anthony (dir). 1999. The Talented Mr Ripley DVD (1999). Paramount \& Miramax.

Minghella, Anthony. 2000. The Talented Mr Ripley screenplay. London: Methuen.

Segal, Naomi. The Unintended Reader: Feminism and 'Manon Lescaut'. Cambridge: Cambridge University Press, 1986 (repr. 2010).

. 'The fatal attraction of Madame Butterfly', in Opera, Exoticism and Visual Culture, eds Hyunseon Lee and Naomi Segal. Bern: Peter Lang, forthcoming 2015.

.Narcissus and Echo: Women in the French Récit. Manchester: Manchester University Press, 1988.

The Adulteress's Child: Authorship and Desire in the Nineteenth-Century Novel. Cambridge: Polity, 1992.

White, Nicholas and Segal, Naomi, eds. Scarlet Letters: Fictions of Adultery from Antiquity to the 1990s. Basingstoke: Macmillan, 1997.

Williams, Michael. 'Plein Soleil and The Talented Mr Ripley: Sun, Stars and Highsmith's Queer Periphery'. Journal of Romance Studies 4: 1 (2004). 47-62.

Birkbeck, University of London 